\title{
Frequency of haemoglobinopathies: a single-centre, cross-sectional study from Islamabad, Pakistan
}

U. Waheed, ${ }^{1}$ H.S. Satti, ${ }^{1}$ N. Farooq ${ }^{2}$ and H.A. Zaheer ${ }^{3}$

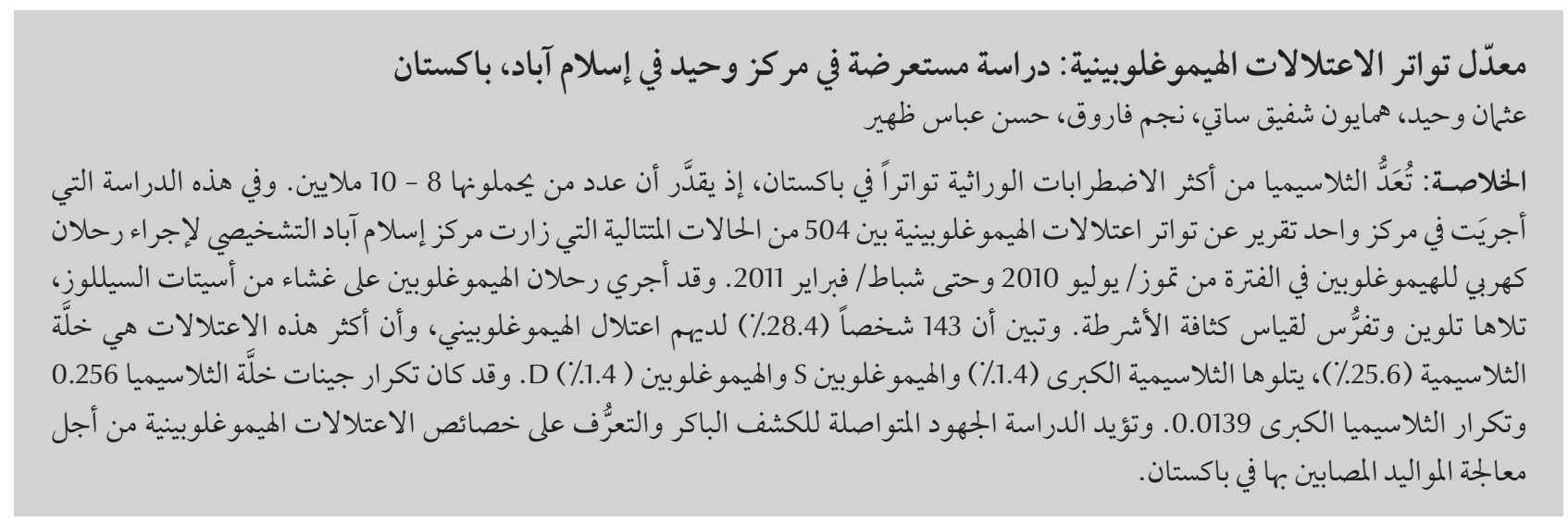

ABSTRACT Thalassaemia is the most frequent hereditary disorder in Pakistan, with an estimated 8-10 million carriers. This single-centre study reported the frequency of haemoglobinopathies among 504 consecutive cases visiting Islamabad Diagnostic Centre for haemoglobin electrophoresis from July 2010 to February 2011. Haemoglobin electrophoresis was performed on cellulose acetate membrane, followed by staining and densitometric scanning of bands. A total of 143 (28.4\%) subjects had haemoglobinopathies. The most predominant was thalassaemia trait (25.6\%), followed by thalassaemia major (1.4\%) and HbS or HbD (1.4\%). The gene frequencies for thalassaemia trait and major were 0.256 and 0.0139 respectively. The study provides support for continuing efforts towards early detection and characterization of haemoglobinopathies to control the affected births in Pakistan.

\section{Fréquence des hémoglobinopathies : étude monocentrique et transversale à Islamabad (Pakistan)}

RÉSUMÉ La thalassémie est l'affection héréditaire la plus fréquente au Pakistan, avec 8 à 10 millions de porteurs selon les estimations. La présente étude monocentrique a étudié la fréquence des hémoglobinopathies chez 504 cas consécutifs en consultation au Centre diagnostique d'Islamabad pour une électrophorèse de I'hémoglobine entre juillet 2010 et février 2011. Une électrophorèse de I'hémoglobine a été réalisée sur une membrane d'acétate de cellulose, suivie par une coloration puis une analyse densitométrique des bandes. Au total, 143 patients $(28,4 \%)$ étaient atteints d'hémoglobinopathies. Le trait thalassémique était I'hémoglobinopathie la plus fréquente $(25,6 \%)$, suivie par la thalassémie majeure $(1,4 \%)$ et l'HbS ou l'HbD $(1,4 \%)$. Les fréquences géniques du trait thalassémique et de la thalassémie majeure étaient de 0,256 et 0,0139 respectivement. La présente étude confirme la nécessité de poursuivre les efforts vers un dépistage et une caractérisation précoces des hémoglobinopathies afin de prévenir la naissance d'enfants porteurs au Pakistan.

'Department of Biochemistry, Quaid-i-Azam University, Islamabad, Pakistan (Correspondence to U. Waheed: usman.waheed07@gmail.com). ${ }^{2}$ Islamabad Diagnostic Centre, Islamabad, Pakistan.

${ }^{3}$ National Programme Manager, National Blood Transfusion Programme, Ministry of Health, Islamabad, Pakistan.

Received: 09/07/2011; accepted: 11/01/12 


\section{Introduction}

Haemoglobinopathies are the most prevalent genetic defect worldwide, with an estimated 269 million carriers [1]. Globally, the populations of certain regions are at higher risk of having a haemoglobinopathy $[1,2]$; while approximately $5 \%$ of the world's population carries a gene for sickle-cell anaemia or thalassaemia, the percentage of carriers can reach $25 \%$ in some regions [3]. A majority of the haemoglobinopathies are not clinically apparent but some produce serious life-threatening diseases and constitute a significant health care burden. These are quantitative (thalassaemia syndromes) or qualitative (variant $\mathrm{Hb}$ ) [4-7]. Thalassaemia syndromes are subclassified based on the gene involved, i.e. $\alpha$ and $\beta$. These $\alpha$-and $\beta$-thalassaemias are further sub-divided into $\alpha+, \beta+$ or $\alpha$,,$\beta 0$ depending on whether some $(+)$ or no (o) globin protein is produced as a result of the causative mutation.

In Pakistan, where the prevalence of thalassaemia is about $5 \%-8 \%[8,9]$, thalassaemia continues to be a health care challenge and burden on affected families and the health care delivery system. The disease runs in families where intermarriages among relatives are common. It is very important to have reliable detection and identification methods for $\mathrm{Hb}$ variants and $\beta$-thalassaemia trait (heterozygous) because this can lead to the prevention of more severe disorders such as thalassaemia major (homozygous) in infants [10]. In recent times successful implementation of national thalassaemia screening programmes in neighbouring countries such as the Islamic Republic of Iran and Turkey have shown a steady decrease in newly registered thalassaemia cases $[7,11]$.

The objective of the present study was to determine the pattern of haemoglobinopathies diagnosed at the Islamabad Diagnostic Centre from July 2010 to February 2011. This is one of the largest private sector diagnostic centres in Islamabad city, Pakistan.

\section{Methods}

\section{Sample}

Five hundred and four (504) cases of anaemia referred from different peripheral hospitals and private clinics from July 2010 to February 2011 were analysed in this study. The research protocol was approved by the medical research review board of Islamabad Diagnostic Centre. All the patients involved in this study were briefed about the objectives of the study and informed consent was obtained from each individual.

\section{Data collection and analysis}

Details of patients' age and sex were recorded. The minimum time elapsed since last blood transfusion, if any, was 3-4 months before the blood sample was taken for analysis.

For each patient a $3 \mathrm{~mL}$ intravenous blood sample was collected in EDTAcontaining vacutainer blood collection tubes. The samples were subjected to testing within 2 hours of sampling using a fully automated blood cell counter (Sysmax KX-21). Haemoglobin electrophoresis was carried out using a commercially available electrophoresis kit comprising of cellulose acetate membrane in tris-EDTA-borate buffer at $\mathrm{pH}$
8.8 (Fisher Biotech). The band densities were measured through a TurboScan digital densitometric analysis system (Fisher Biotech). An HbA2 value $>3.5 \%$ was considered as a cut-off point for beta-thalassaemia trait. The red blood cell indices were compatible with thalassaemia trait in all cases where the $\mathrm{HbA2}$ gene was raised.

The gene frequency of different haemoglobinopathies was estimated using the Hardy-Weinberg equilibrium $p^{2}+$ $2 p q+q^{2}=1$, where $p$ is the frequency of the $\mathrm{A}$ allele in the population and $q$ is the frequency of the a allele in the population. The frequencies of genotypes in the population are given by: $p^{2}$ for genotype AA, $2 p q$ for genotype Aa, $q^{2}$ for genotype aa.

\section{Results}

Out of the total 504 cases, 226 were male (44.8\%) and 278 were female (55.2\%), with median ages 22.6 years and 24.2 years respectively. Overall, 361 subjects $(71.6 \%)$ had a normal haemoglobin pattern, while a raised HbA2 haemoglobinopathy was seen in $143(28.4 \%)$ cases (Figure 1). Among these, $129(25.6 \%)$ had the thalassaemia trait gene, 7 had thalassaemia

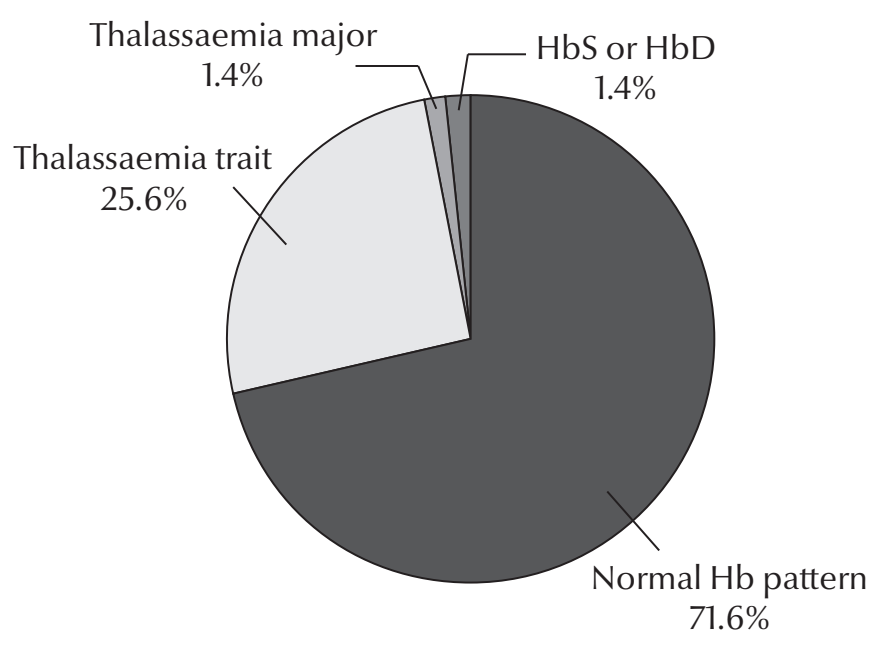

Figure 1 Percentage of normal haemoglobin $(\mathrm{Hb})$ and haemoglobinopathies detected in 504 cases of anaemia at a referral centre in Islamabad, Pakistan 


\begin{tabular}{lcccc}
\hline Table 1 Spectrum of $\mathbf{1 4 3}$ haemoglobinopathies detected in & 504 cases of anaemia at a referral centre in Islamabad, Pakistan \\
\hline Haemoglobinopathy & No. of cases & $\%$ & Cumulative \% & Gene frequency \\
Thalassaemia trait (+/-) & 129 & 90.2 & 90.2 & 0.256 \\
Thalassaemia major (-/-) & 7 & 4.9 & 95.1 & 0.0139 \\
HbS or HbD & 7 & 4.9 & 100.0 & 0.0139 \\
Total & 143 & 100.0 & - & - \\
\hline
\end{tabular}

$H b S=$ sickle cell haemoglobin; $H b D=$ haemoglobin D variant (Punjab).

major $(1.4 \%)$ and the remaining 7 patients were found to have $\mathrm{HbS}$ or $\mathrm{HbD}(1.4 \%)$. The frequencies of different haemoglobinopathies and their respective gene frequencies are shown in Table 1.

\section{Discussion}

The overall frequency of haemoglobinopathies in this study was $28.4 \%$, which is comparable to a previously presented series of 2000 cases from a referral laboratory in the region revealing that $28.2 \%$ cases presented with haemoglobinopathies [12]. The results of this study also support the finding that thalassaemia is the most frequent form of haemoglobinopathy in Pakistan [13]. The cumulative percentage of thalassaemia genes among individuals having haemoglobinopathies was $95.1 \%$ in this study, compared with $90.1 \%$ in another earlier study [12].

This high frequency of thalassaemia genes reflects the high regional and geographical prevalence $[8,10]$. The estimated thalassaemia gene frequency in Pakistan is around $5 \%-8 \%$, with $8-10$ million carriers and 6000 children born with thalassaemia major every year $[8,9]$. This is partly because of the high ratio of consanguineous cousin marriages and poor access to education and health facilities [14], and also due to lack of a national thalassaemia screening and prevention programme in Pakistan. In Pakistan, the concept of thalassaemia prevention is gaining momentum and a new bill on thalassaemia prevention has been put forward in the National Assembly. Our results provide support for these continuing efforts towards early detection and characterization of haemoglobinopathies for the control and prevention of affected births.

\section{Acknowledgement}

We are thankful to Mr Anwar Ullah, Haematology Department, Islamabad Diagnostic Centre for his assistance and cooperation.

\section{References}

1. Weatherall DJ, Clegg JB. Inherited haemoglobin disorders: an increasing global health problem. Bulletin of the World Health Organization, 2001, 79:704-712.

2. Angastiniotis M, Modell B. Global epidemiology of hemoglobin disorders. Annals of the New York Academy of Sciences, 1998, 850:251-269.

3. Sickle cell anemia and other hemoglobinopathies. Fact Sheet No. 308. Geneva, World Health Organization, 2006.

4. Kutlar F. Diagnostic approach to hemoglobinopathies. Hemoglobin, 2007, 31:243-250.

5. Clarke GM, Higgins TN. Laboratory investigation of hemoglobinopathies and thalassemias: review and update. Clinical Chemistry, 2000, 46:1284-1290.

6. Colah RB et al. HPLC studies in hemoglobinopathies. Indian Journal of Pediatrics, 2007, 74:657-662.

7. Samavat A, Modell B. Iranian national thalassaemia screening programme. British Medical Journal, 2004, 329:11341137.

8. Hafeez M et al. Regional and ethnic distribution of beta thalassemia mutations and effect of consanguinity in patients referred for prenatal diagnosis. Journal of the College of Physicians and Surgeons of Pakistan, 2007, 17:144-147.
9. Tasleem S et al. Prenatal diagnosis of beta-thalassaemia by chorionic villous sampling. Journal of the Pakistan Medical Association, 2007, 57:528-531.

10. Sachdev R, Dam AR, Tyagi G. Detection of Hb variants and hemoglobinopathies in Indian population using HPLC: report of 2600 cases. Indian Journal of Pathology and Microbiology, 2010, 53:57-62.

11. Canatan D et al. Hemoglobinopathy control program in Turkey. Community Genetics, 2006, 9:124-126.

12. Atta T et al. Frequency of haemoglobin disorders experience at Armed Forces Institute of Pathology. Abstract presented at the 12th Annual Conference of the Pakistan Society of Haematology, 14-15 February, 2009.

13. Khateeb B et al. Genetic diversity of beta-thalassemia mutations in Pakistani population. Journal of the Pakistan Medical Association, 2000, 50:293-296.

14. Abdullah KN, Azim W, Liaqat J. Beta-thalassemia-institution based analysis of ethnic and geographic distribution, effect of consanguinity and safety of chorionic villus sampling as a diagnostic, tool for pre-natal diagnosis in selected patients. Pakistan Armed Forces Medical Journal, 2010, 4:77-80. 